\title{
How Specific Gravity Applicable with Freckles?
}

\author{
Muhammad Imran Qadir and Aqsa Asghar* \\ Institute of Molecular Biology and Biotechnology, Multan, Pakistan \\ *Corresponding author: Aqsa Asghar, Institute of Molecular Biology and Biotechnology, Multan, Pakistan
}

\begin{tabular}{|c|c|}
\hline ARTICLE INFO & ABSTRACT \\
\hline Received: 蔧 April 15, 2019 & The aim of the present study was to find the link between specific gravity or freckles. \\
\hline Published: 慧 April 22, 2019 & $\begin{array}{l}\text { During the sampling collection, we inquired them that what concentration of urine } \\
\text { specific gravity presents in them. These mates are students of University. Specific gravity }\end{array}$ \\
\hline $\begin{array}{l}\text { Citation: Muhammad Imran Qadir, } \\
\text { Aqsa Asghar. How Specific Gravity } \\
\text { Applicable with Freckles?.Biomed } \\
\text { J Sci \& Tech Res 17(2)-2019. BJSTR. } \\
\text { MS.ID.002972. }\end{array}$ & $\begin{array}{l}\text { is the increased concentration of solutes in the urine. Increased concentration of specific } \\
\text { gravity associated with diarrhea, dehydration, glucosuria. But on the other side decreased } \\
\text { the concentration of specific gravity associated with renal failure, diabetes etc. Freckles } \\
\text { are small brown spots on the skin. Freckles are caused by the production of melanin } \\
\text { on surface of the skin. We concluded that there is a relationship between normal body } \\
\text { temperature or freckles. }\end{array}$ \\
\hline
\end{tabular}

Keywords: Dark spot; Specific gravity; Urine

\section{Introduction}

Specific gravity is the increased concentration of solutes in the urine. Increased concentration of specific gravity associated with diarrhea, dehydration, glucosuria. But on the other side decreased a concentration of specific gravity associated with renal failure, diabetes etc. density of urine to density of water compared by urine specific gravity. Doing a urine test is a very difficult task for the doctor. specific gravity test also shows the concentration of chemical particles in the urine. Before urines specific gravity test you have to stop the medication [1]. The normal range of urine specific gravity test is 1.25 . the increased amount of specific gravity causes the bacterial infection or during pregnancy also complicate the pregnancy. Freckles are small brown spots on the skin. Freckles are caused by the production of melanin on surface of the skin. They darken the skin or made small patches on the skin surface. Melanin is produced by skin exposure. Melanin production increase during pregnancy. Mostly melanin produces on the dark skin, but small patches make on the fair skin [2]. Objective of the present study was to show the linked between urine specific gravity and freckles.

\section{Materials and Methods}

\section{Measurement of Urine Specific Gravity}

We took the plastic bag for sampling collection. Then we go to the toilet and opened the lid of the sample bag. Then we cleaned the genital area with cotton prevent from contamination [3-5]. We collect the sample under the stream of urination. Then we closed the lid of the plastic bag. We got the strips from the supervisor and dipped in the sample. The color changes occurred, and the value of urine specific gravity is calculated.

\section{Project Designing}

During the sampling collection, we inquired them what concentration of urine specific gravity presents in them. Then we related it with the freckle absence or presence. 100 mates concerned about the project. These mates are students of the University.

\section{Statistical Analysis}

Statistical analysis is got by the usage of M State software. A t-test was performed to get the results of the data. A probability value of less than 0.001 was said to be significant.

\section{Results and Discussions}

Above table reveals that the agents who have freckles have to mean specific gravity value of 0.93 with standard deviation 0.30 and those who don't have a mean specific gravity value of 1.03 with SD 0.004 [6-8]. The probability value obtained is 0.29 which is not significant as it is greater than 0.01 . The ladies who have mean specific gravity of 1.01 with SD 0.14 and those who don't have to mean specific gravity 0.92 with standard deviation 0.31 . The p-value measured is 0.14 which is also not significant as it is greater.

\section{Conclusion}

It is concluded that there is no correspondence of urine specific gravity with freckles. 


\section{References}

1. Qadir MI, Javid A (2018) Awareness about Crohn's Disease in biotechnology students. Glo Adv Res J Med Medical Sci 7(3): 62-64.

2. Qadir MI, Saleem A (2018) Awareness about ischemic heart disease in university biotechnology students. Glo Adv Res J Med Medical Sci 7(3): 59-61.

3. Qadir MI, Ishfaq S (2018) Awareness about hypertension in biology students. Int J Mod Pharma Res 7(2): 08-10.

4. Qadir MI, Mehwish (2018) Awareness about psoriasis disease. Int J Mod Pharma Res 7(2): 17-18.

\section{ISSN: 2574-1241}

DOI: 10.26717/BJSTR.2019.17.002972

Aqsa Asghar. Biomed J Sci \& Tech Res

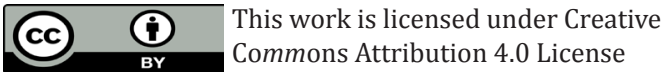

Submission Link: https://biomedres.us/submit-manuscript.php
5. Qadir MI, Shahzad R (2018) Awareness about obesity in postgraduate students of biotechnology. Int J Mod Pharma Res 7(2): 14-16.

6. Qadir MI, Rizvi M (2018) Awareness about thalassemia in post graduate students. MOJ Lymphology \& Phlebology 2(1): 14-16.

7. Qadir MI, Ghalia BA (2018) Awareness survey about colorectal cancer in students of M. Phil Biotechnology at Bahauddin Zakariya University, Multan, Pakistan. Nov Appro in Can Study 1(3): NACS.000514.2018.

8. Qadir MI, Saba G (2018) Awareness about intestinal cancer in university student. Nov Appro in Can Study 1(3): NACS.000515.2018.

$\begin{array}{ll}\text { BIOMEDICAL } & \text { Assets of Publishing with us } \\ \text { RESEARCHES } & \text { - Global archiving of articles } \\ & \text { - Immediate, unrestricted online access } \\ \end{array}$

